\title{
Sistem Informasi Pelaporan Komplain Dan Monitoring Perbaikan Sarana Dan Prasarana Berbasis Android
}

\author{
Zainul Anwar ${ }^{1}$, Hari Lugis Purwanto ${ }^{2}$, Rini Agustina ${ }^{3}$ \\ Sistem Informasi, Universitas Kanjuruhan Malang 1,2,3 \\ zainulanwar244@gmail.com \\ hari_lugis@unikama.ac.id \\ riniagustina@unikama.ac.id
}

\begin{abstract}
Abstrak. Prosedur pelaporan komplain secara lisan dan telepon terkadang menyebabkan kepala bagian atau staff unit perlengkapan Universitas Kanjuruhan Malang lupa akan komplain yang sudah dilaporkan, karena banyaknya laporan komplain yang berasal dari beberapa unit yang berbeda. Selain itu apabila pelapor tidak bertemu teknisi pada saat proses penanganan perbaikan dilakukan menyebabkan pelapor tidak mengetahui informasi penanganan perbaikan. Dari permasalahan tersebut diperlukan sebuah sistem yang diharapkan dapat membantu unit perlengkapan dalam proses penanganan komplain dan membantu staff unit untuk mengetahui informasi penanganan perbaikan. Proses perancangan dan pembangunan sistem ini menggunakan metodologi SDLC (Software Development Life Cycle) yaitu Waterfall Model. Berdasarkan hasil pengujian menggunakan UAT (User Acceptance Test) untuk menguji kelayakan sistem mendapatkan hasil $86 \%$ dari 11 responden yang menyatakan setuju jika sistem digunakan pada Universitas Kanjuruhan Malang.
\end{abstract}

Kata Kunci: sistem informasi, pelaporan komplain, monitoring perbaikan

\section{PENDAHULUAN}

Permasalahan yang terjadi dari melaporkan komplain menggunakan lisan secara langsung dan telepon adalah terkadang kepala bagian atau staff unit perlengkapan lupa akan komplain yang sudah dilaporkan, karena banyaknya laporan komplain yang berasal dari beberapa unit yang berbeda di Universitas Kanjuruhan Malang. Hal tersebut menyebabkan lamanya proses penanganan komplain yang dilaporkan apabila pelapor tidak melaporkan ulang komplain tersebut.

Pada proses penanganan komplain saat ini berdasarkan dokumen IK (Instruksi Kerja) penanganan komplian unit perlengkapan, kepala bagian atau staff unit perlengkapan menerima komplain, kemudian melakukan pengecekan barang ke lokasi dan menindaklanjuti komplain yang dilaporkan. Apabila kerusakan barang termasuk kerusakan ringan maka ditindaklanjuti dengan perbaikan kemudian kepala bagian atau teknisi perlengkapan membuat laporan terhadap hasil penanganan komplain dan menghubungi unit yang mengkomplain bahwa komplain telah terlaksana untuk approval. Apabila kerusakan barang termasuk kerusakan berat maka barang akan dibawa ke gudang untuk perbaikan lebih lanjut. Barang yang tidak dapat ditangani oleh teknisi maka akan diserviskan ke rekanan.

Permasalahan yang terjadi apabila pada saat proses perbaikan barang di lokasi sedang dilakukan oleh teknisi dan teknisi tidak bertemu dengan staff unit yang melapor maka proses penanganan komplain tidak diketahui oleh staff unit yang melaporkan. Hal ini menyebabkan terjadinya pelaporan komplain berulang karena staff unit berpikir bahwa laporan komplainnya belum ditangani padahal sudah ditangani atau dalam proses perbaikan teknisi perlengkapan. Selain pelapor, kepala bagian unit perlengkapan juga tidak mendapatkan informasi proses penanganan laporan komplain yang menyebabkan laporan komplain yang tidak ditangani oleh teknisi unit perlengkapan tidak mendapatkan proses tindak lanjut dari kepala bagian unit 
perlengkapan untuk segera ditangani oleh teknisi yang bersangkutan. Saat ini apabila kepala bagian perlengkapan ingin mengetahui laporan komplain yang tidak ditangani harus turun ke lapangan langsung untuk melakukan pemantauan kinerja teknisi unit perlengkapan sekaligus mengetahui sampai mana penanganan sarana dan prasarana yang dilaporkan oleh pelapor.

\section{METODE PENELITIAN}

\section{Model Pengembangan Waterfall}

Penelitian ini menggunakan model Software Development Life Cycles (SDLC) dalam melakukan pengembangan produk. Model tersebut merupakan tahapan-tahapan pekerjaan yang dilakukan oleh analis sistem dan programmer dalam membangun sistem informasi (Dwanoko, 2016). Pengembangan produk yang dilakukan menggunakan model waterfall yang setiap langkahnya harus dilakukan secara berurutan. Secara ringkas model waterfall dapat dilihat pada gambar 1 dibawah ini:

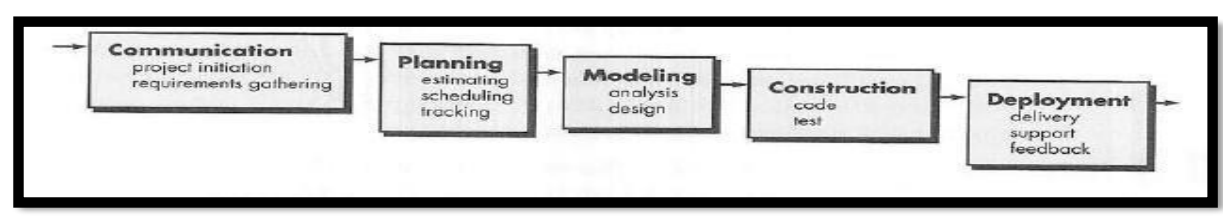

Gambar 1. Model Waterfall (Pressman, 2015)

\section{a) Communication}

Berdasarkan hasil analisa masalah yang dilakukan di lapangan maka dilakukan project initiation yaitu sistem pelaporan komplain dan monitoring penanganan perbaikan pada Universitas Kanjuruhan Malang yang diharapkan dapat membantu pengguna dalam proses pelaporan komplain dan monitoring penanganan perbaikan sarana dan prasarana. Kemudian pada tahap requirement gathering dilakukan observasi dan wawancara yang nantinya dapat ditentukan kebutuhan fungsional apa saja yang diperlukan dalam sistem.

\section{b) Planning}

Pada tahap ini peneliti melakukan perencanaan yang menjelaskan tentang sumber daya yang diperlukan dan estimasi tugas yang akan dilakukan dalam pembuatan sistem pelaporan komplain dan monitoring perbaikan di Universitas Kanjuruhan Malang yang mengacu pada hasil tahap communication. Hal tersebut dilakukan dengan menentukan estimasi pengerjaan sistem kemudian membuat penjadwalan pengerjaan sistem dan melakukan tracking pengerjaan sistem sesuai dengan jadwal pengerjaan sistem yang telah dibuat. Adapun Estimasi pengerjaan sistem pelaporan komplain dan monitoring perbaikan sarana dan prasarana pada Universitas Kanjuruhan Malang adalah 30 Minggu terhitung sejak tanggal 31 Oktober 2019 s/d 10 Juni 2020.

\section{c) Modelling}

Pada tahap modelling dilakukan pembuatan desain block diagram dan perancangan desain sistem menggunakan UML (Unified Modelling Language) yang terdiri dari use case diagram utama, sub use case, activity diagram, sequence diagram dan class diagram serta desain user interface sistem. Menurut Tohari dalam Tabrani dan Aghniya (2019:46), use case adalah rangkaian atau uraian sekelompok yang saling terkait dan membentuk sistem secara teratur yang dilakukan atau diawasi oleh sebuah aktor. Diagram kelas atau class merupakan hubungan antar kelas dan penjelasan detail tiap-tiap kelas di dalam model desain dari suatu sistem, juga memperlihatkan aturan-aturan dan tanggung jawab entitas yang menentukan perilaku sistem (Hendini, 2016).

Desain block diagran berfungsi sebagai alur yang menjadi acuan dalam membangun sistem sedangkan pembuatan rancangan sistem dan desain user interface bertujuan untuk mempermudah proses pembangunan sistem pelaporan komplain dan monitoring perbaikan sarana prasarana pada Universitas Kanjuruhan Malang berbasis android. 


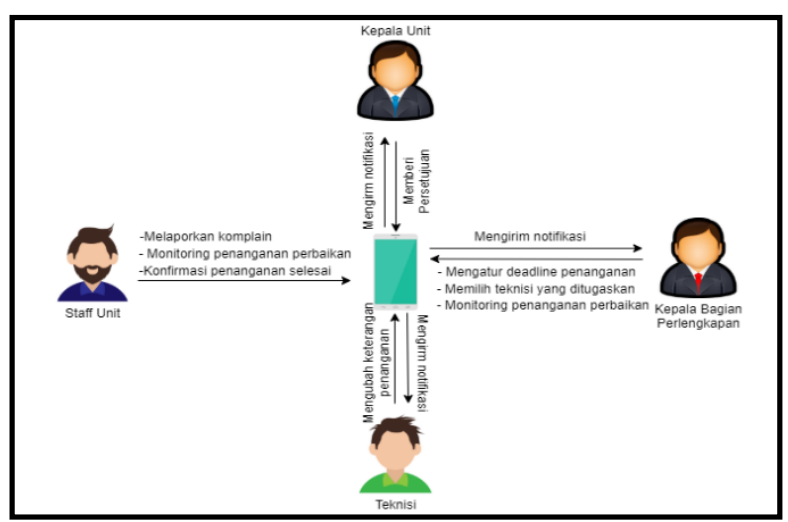

Gambar 2. Block Diagram

Block diagram menampilkan alur berjalannya sistem mulai dari proses pelaporan komplain oleh staff unit hingga proses konfirmasi penanganan selesai apabila laporan komplain sudah selesai dilakukan oleh teknisi.

\section{d) Construction (Coding)}

Pada tahap construction, peneliti melakukan pemrograman atau disebut development yang menyesuaikan dengan desain produk yang telah dibuat pada tahap modelling sebelumnya. Software yang digunakan adalah Android Studio, Sublime Text 3, XAMPP, dan Postman.

Setelah melakukan coding sistem, maka selanjutnya akan dilakukan pengujian untuk mendapatkan kekurangan dan kelemahan pada sistem yang telah dibuat untuk selanjutnya dilakukan perbaikan sebelum sistem diimplementasikan di lapangan.

\section{e) Deployment}

Tahap ini adalah tahap implementasi sistem ke pengguna, pemeliharaan sistem secara berkala, pengembangan sistem berdasarkan feedback yang diberikan agar sistem tetap berjalan dan berkembang sesuai dengan fungsinya. Pada tahap ini dilakukan penyebaran angket UAT (User Acceptance Test) untuk mengukur tingkat kelayakan sistem yang hasilnya dapat digunakan untuk proses pemeliharaan dan pengembangan sistem. Menurut Betha dalam Wahyuningsih dan Wibawa (2017), User Acceptance Test (UAT) atau uji penerimaan pengguna adalah suatu proses pengujian oleh pengguna yang dimaksudkan untuk menghasilkan dokumen yang dijadikan bukti bahwa software yang telah dikembangkan dapat diterima oleh pengguna, apabila hasil pengujian (testing) sudah bisa dianggap memenuhi kebutuhan dari pengguna.

\section{HASIL DAN PEMBAHASAN}

Use case diagram utama menjelaskan daftar aktor yang terlibat di dalam sistem dan hak akses yang dapat dilakukan oleh masing-masing aktor.

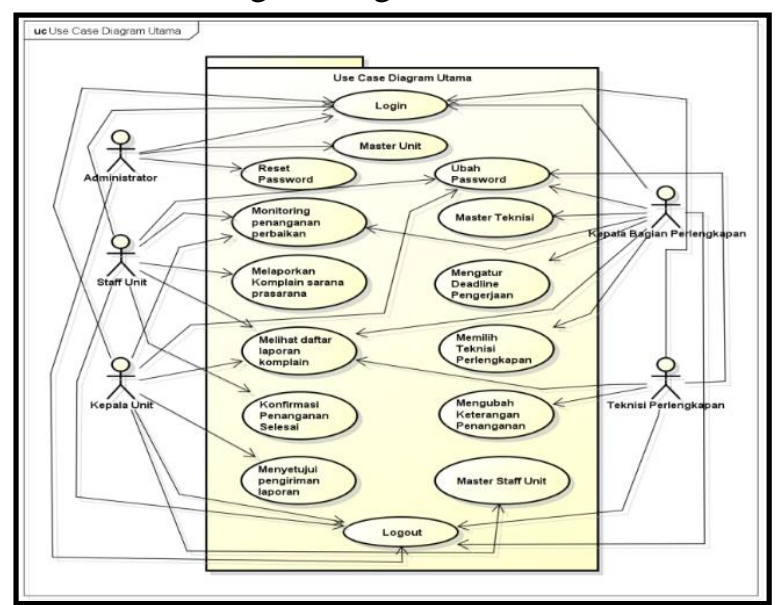

Gambar 3. Use Case Diagram Utama 
Berikut merupakan tabel penjelasan mengenai use case diagram utama sistem :

Tabel 1. Penjelasan Use Case Diagram Utama

\begin{tabular}{|c|c|c|c|}
\hline No. & Aktor & Peran & Hak Akses \\
\hline 1. & Administrator & $\begin{array}{l}\text { Berperan sebagai pengelola } \\
\text { master data unit }\end{array}$ & $\begin{array}{l}\text { Master unit } \\
\text { Reset password pengguna }\end{array}$ \\
\hline 2. & Staff unit & $\begin{array}{l}\text { Berperan sebagai pelapor } \\
\text { komplain sarana prasarana yang } \\
\text { rusak. }\end{array}$ & $\begin{array}{l}\text { Melakukan pelaporan komplain } \\
\text { Monitoring penanganan } \\
\text { Melihat daftar laporan komplain } \\
\text { Konfirmasi penanganan selesai } \\
\text { Mengubah password }\end{array}$ \\
\hline 3. & Kepala unit & $\begin{array}{l}\text { Berperan sebagai penentu } \\
\text { apakah laporan akan di } \\
\text { kirimkan ke kepala bagian unit } \\
\text { perlengkapan }\end{array}$ & $\begin{array}{l}\text { Memberi persetujuan laporan } \\
\text { komplain } \\
\text { Melihat daftar laporan komplain } \\
\text { Monitoring penanganan } \\
\text { Master staff unit } \\
\text { Mengubah password }\end{array}$ \\
\hline 4. & $\begin{array}{l}\text { Kepala bagian unit } \\
\text { perlengkapan }\end{array}$ & $\begin{array}{l}\text { Berperan mengatur deadline } \\
\text { pengerjaan dan memilih teknisi } \\
\text { yang akan ditugaskan untuk } \\
\text { menangani komplain }\end{array}$ & $\begin{array}{l}\text { Master teknisi } \\
\text { Monitoring penanganan } \\
\text { Mengatur deadline } \\
\text { Memilih teknisi } \\
\text { Mengubah password }\end{array}$ \\
\hline 5. & $\begin{array}{l}\text { Teknisi unit } \\
\text { perlengkapan }\end{array}$ & $\begin{array}{l}\text { Berperan sebagai aktor yang } \\
\text { menangani laporan komplain } \\
\text { sarana dan prasarana serta } \\
\text { mengubah keterangan } \\
\text { penanganan apabila terjadi } \\
\text { perubahan tindakan penanganan } \\
\text { perbaikan. }\end{array}$ & $\begin{array}{l}\text { Melihat daftar laporan } \\
\text { Mengubah keterangan penanganan } \\
\text { laporan } \\
\text { Mengubah password }\end{array}$ \\
\hline
\end{tabular}

Class diagram menjelaskan hubungan antara kelas pada sistem serta atribut dan properti yang ada pada tiap kelas. Secara ringkas class diagram sistem dapat dilihat pada gambar 4.

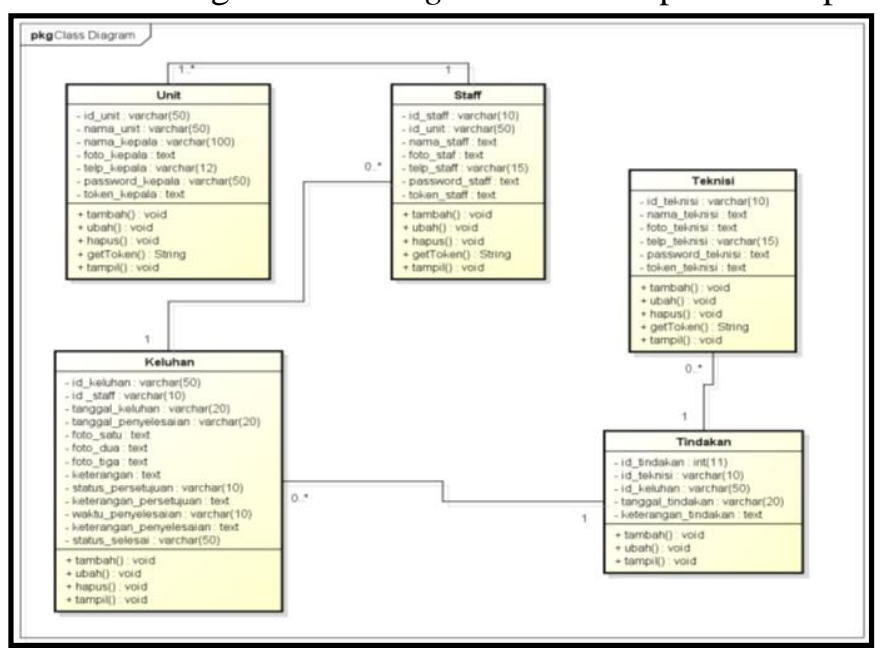

Gambar 4. Class Diagram

Setelah proses perancangan sistem menggunakan UML selesai dilakukan maka selanjutnya dibuat rancangan user interface sistem. Berikut rancangan user interface sistem pada form pelaporan komplain pada gambar 5. 


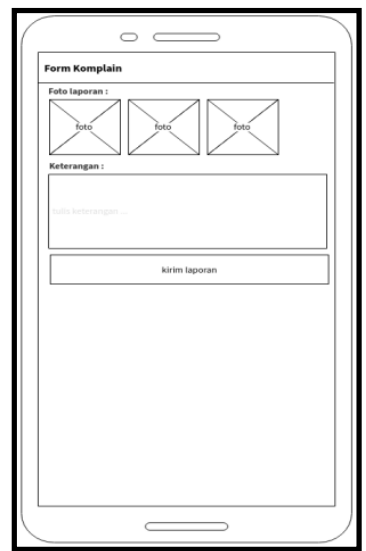

Gambar 5. User Interface Form Pelaporan Komplain

Pada tahap construction dilakukan proses coding atau pembangunan sistem yang mengacu pada rancangan sistem yang telah dibuat pada tahapan sebelumnya. Berikut tampilan sistem pada form pelaporan komplain.

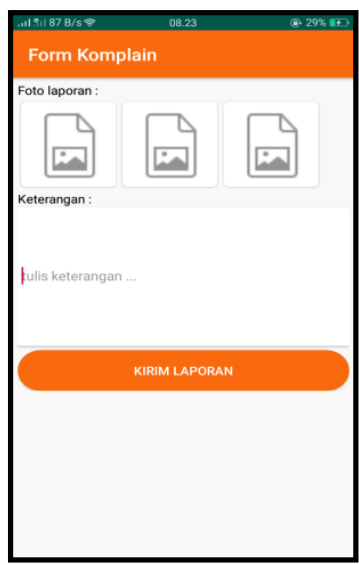

\section{Gambar 6. Tampilan Form Pelaporan Komplain}

Setelah proses pembuatan sistem selesai dilakukan, maka dilakukan pengujian pada sistem. Pengujian dilakukan dengan bertujuan untuk mengetahui kesalahan sistem dan mengetahui apakah sistem yang telah dibuat sesuai dengan yang diinginkan. Apabila terdapat kesalahan pada sistem maka dilakukan revisi produk. Berikut merupakan tabel hasil pengujian sistem menggunakan blackbox testing :

Tabel 2. Pengujian Sistem Black Box Testing

\begin{tabular}{|c|c|c|c|c|c|}
\hline No. & Fungsi & Pengujian & $\begin{array}{l}\text { Hasil yang } \\
\text { Diharapkan }\end{array}$ & Hasil Pengujian & Keterangan \\
\hline 1. & $\begin{array}{l}\text { Melaporkan } \\
\text { keluhan }\end{array}$ & $\begin{array}{l}\text { Tambahkan } \\
\text { foto laporan } \\
\text { dan keterangan } \\
\text { lalu tekan } \\
\text { tombol kirim } \\
\text { laporan }\end{array}$ & $\begin{array}{l}\text { Laporan } \\
\text { berhasil } \\
\text { disimpan dan } \\
\text { mengirim } \\
\text { notifikasi ke } \\
\text { kepala unit }\end{array}$ & $\begin{array}{l}\text { Berhasil } \\
\text { mengirim laporan } \\
\text { ke kepala unit }\end{array}$ & sesuai \\
\hline 2. & $\begin{array}{l}\text { Melaporkan } \\
\text { keluhan (data } \\
\text { tidak lengkap) }\end{array}$ & $\begin{array}{l}\text { Mengisi form } \\
\text { komplain } \\
\text { secara tidak } \\
\text { lengkap lalu } \\
\text { tekan tombol } \\
\text { kirim laporan }\end{array}$ & $\begin{array}{l}\text { Sistem tidak } \\
\text { akan } \\
\text { menyimpan dan } \\
\text { tidak mengirim } \\
\text { notifikasi ke } \\
\text { kepala unit }\end{array}$ & $\begin{array}{l}\text { Sistem } \\
\text { menampilkan } \\
\text { pesan wajib diisi } \\
\text { pada bidang input } \\
\text { yang kosong dan } \\
\text { laporan tidak } \\
\text { dikirim }\end{array}$ & sesuai \\
\hline 3. & $\begin{array}{l}\text { Melihat daftar } \\
\text { laporan }\end{array}$ & $\begin{array}{l}\text { Memilih menu } \\
\text { daftar laporan }\end{array}$ & $\begin{array}{l}\text { Sistem } \\
\text { menampilkan }\end{array}$ & $\begin{array}{l}\text { Sistem } \\
\text { menampilkan }\end{array}$ & sesuai \\
\hline
\end{tabular}




\begin{tabular}{|c|c|c|c|c|c|}
\hline & keluhan (staff) & & $\begin{array}{l}\text { daftar laporan } \\
\text { keluhan sesuai } \\
\text { id user staff }\end{array}$ & $\begin{array}{l}\text { daftar laporan } \\
\text { keluhan dalam } \\
\text { bentuk list }\end{array}$ & \\
\hline 4. & $\begin{array}{l}\text { Menyetujui } \\
\text { pengiriman } \\
\text { laporan }\end{array}$ & $\begin{array}{l}\text { Mengisi data } \\
\text { form } \\
\text { persetujuan } \\
\text { lalu tekan } \\
\text { tombol simpan }\end{array}$ & $\begin{array}{l}\text { Sistem akan } \\
\text { mengirim } \\
\text { notifikasi } \\
\text { laporan ke } \\
\text { kepala bagian } \\
\text { perlengkapan } \\
\text { jika disetujui }\end{array}$ & $\begin{array}{l}\text { Sistem mengirim } \\
\text { notifikasi laporan } \\
\text { ke kepala bagian } \\
\text { perlengkapan jika } \\
\text { disetujui }\end{array}$ & sesuai \\
\hline 5. & $\begin{array}{l}\text { Menyetujui } \\
\text { pengiriman } \\
\text { laporan (data } \\
\text { tidak lengkap) }\end{array}$ & $\begin{array}{l}\text { Mengisi data } \\
\text { form } \\
\text { persetujuan } \\
\text { secara tidak } \\
\text { lengkap lalu } \\
\text { tekan tombol } \\
\text { simpan }\end{array}$ & $\begin{array}{l}\text { Sistem tidak } \\
\text { akan } \\
\text { menyimpan } \\
\text { data persetujuan } \\
\text { dan } \\
\text { menampilkan } \\
\text { pesan wajib } \\
\text { diisi pada } \\
\text { bidang input } \\
\text { yang kosong }\end{array}$ & $\begin{array}{l}\text { Sistem tidak akan } \\
\text { menyimpan data } \\
\text { persetujuan dan } \\
\text { menampilkan } \\
\text { pesan wajib diisi } \\
\text { pada bidang input } \\
\text { yang kosong }\end{array}$ & sesuai \\
\hline 6. & $\begin{array}{l}\text { Melihat daftar } \\
\text { laporan } \\
\text { keluhan } \\
\text { (kepala unit) }\end{array}$ & $\begin{array}{l}\text { Memilih menu } \\
\text { laporan sudah } \\
\text { ditanggapi }\end{array}$ & $\begin{array}{l}\text { Sistem } \\
\text { menampilkan } \\
\text { daftar laporan } \\
\text { yang sudah } \\
\text { ditanggapi } \\
\text { kepala unit }\end{array}$ & $\begin{array}{l}\text { Sistem } \\
\text { menampilkan } \\
\text { daftar laporan } \\
\text { yang sudah } \\
\text { ditanggapi kepala } \\
\text { unit }\end{array}$ & sesuai \\
\hline 7. & $\begin{array}{l}\text { Mengatur } \\
\text { deadline } \\
\text { pengerjaan }\end{array}$ & $\begin{array}{l}\text { Mengisi form } \\
\text { set deadline } \\
\text { lalu tekan } \\
\text { tombol simpan }\end{array}$ & $\begin{array}{l}\text { Sistem } \\
\text { menampilkan } \\
\text { daftar teknisi } \\
\text { yang akan } \\
\text { dipilih } \\
\end{array}$ & $\begin{array}{l}\text { Sistem } \\
\text { menampilkan } \\
\text { daftar teknisi } \\
\text { yang akan dipilih }\end{array}$ & sesuai \\
\hline 8. & $\begin{array}{l}\text { Mengatur } \\
\text { deadline } \\
\text { pengerjaan } \\
\text { (data tidak } \\
\text { lengkap) }\end{array}$ & $\begin{array}{l}\text { Mengisi form } \\
\text { set deadline } \\
\text { secara tidak } \\
\text { lengkap lalu } \\
\text { tekan tombol } \\
\text { simpan } \\
\end{array}$ & $\begin{array}{l}\text { Sistem } \\
\text { menampilkan } \\
\text { pesan wajib } \\
\text { diisi pada } \\
\text { bidang input } \\
\text { yang kosong }\end{array}$ & $\begin{array}{l}\text { Sistem } \\
\text { menampilkan } \\
\text { pesan wajib diisi } \\
\text { pada bidang input } \\
\text { yang kosong }\end{array}$ & sesuai \\
\hline 9. & $\begin{array}{l}\text { Memilih } \\
\text { teknisi } \\
\text { perlengkapan }\end{array}$ & $\begin{array}{l}\text { Memilih } \\
\text { teknisi lalu } \\
\text { tekan tombol } \\
\text { pilih pada list } \\
\text { teknisi }\end{array}$ & $\begin{array}{l}\text { Data disimpan } \\
\text { oleh sistem dan } \\
\text { notifikasi akan } \\
\text { dikirim ke } \\
\text { teknisi yang } \\
\text { dipilih }\end{array}$ & $\begin{array}{l}\text { Data disimpan } \\
\text { oleh sistem dan } \\
\text { notifikasi akan } \\
\text { dikirim ke } \\
\text { teknisi yang } \\
\text { dipilih }\end{array}$ & sesuai \\
\hline 10. & $\begin{array}{l}\text { Mengubah } \\
\text { status } \\
\text { penanganan }\end{array}$ & $\begin{array}{l}\text { Mengisi form } \\
\text { ubah status } \\
\text { penanganan } \\
\text { lalu tekan } \\
\text { tombol simpan }\end{array}$ & $\begin{array}{l}\text { Data } \\
\text { penanganan } \\
\text { akan disimpan } \\
\text { oleh sistem }\end{array}$ & $\begin{array}{l}\text { Data penanganan } \\
\text { akan disimpan } \\
\text { oleh sistem }\end{array}$ & sesuai \\
\hline
\end{tabular}

\section{Pembahasan Produk}

Sistem informasi pelaporan komplain dan monitoring perbaikan sarana prasarana berbasis android adalah sistem yang diharapkan dapat membantu proses pelaporan komplain dan monitoring perbaikan sarana prasarana antara unit perlengkapan dengan unit yang lain di Universitas Kanjuruhan Malang. Terdapat beberapa hak akses yang terdapat pada sistem yaitu administrator, kepala unit, kepala bagian perlengkapan, staff unit, dan teknisi perlengkapan. Monitoring dapat dilakukan oleh staff unit, kepala unit, dan kepala bagian perlengkapan.

Proses pelaporan komplain dan monitoring penanganan perbaikan dalam sistem dimulai dengan pengguna login terlebih dahulu sesuai dengan hak aksesnya dengan memasukkan id user 
dan password. Staff unit mengisi form pelaporan komplain pada sistem dan mengirim laporan. Sistem akan mengirim notifikasi kepada kepala unit bahwa ada laporan komplain dari staff unit yang bersangkutan. Kepala unit memberikan tanggapan persetujuan kepada laporan komplain yang masuk. Sistem akan mengirim notifikasi laporan masuk kepada kepala bagian perlengkapan. Selanjutnya kepala bagian perlengkapan memberikan tanggapan untuk laporan komplain yang baru masuk dengan mengatur estimasi penyelesaian penanganan dan memilih teknisi yang akan ditugaskan untuk menangani perbaikan. Sistem akan mengirim notifikasi tugas baru untuk teknisi yang telah ditugaskan. Teknisi mengubah keterangan penanganan laporan, apabila penanganan perbaikan telah selesai dilakukan maka teknisi dapat menekan tombol penanganan selesai yang nantinya staff unit akan melakukan konfirmasi penanganan selesai pada sistem.

Pengujian sistem yang telah dilakukan oleh peneliti mendapatkan hasil bahwa sistem mampu mengirimkan notifikasi laporan komplain, menyimpan data laporan komplain dan menampilkan keterangan penanganan perbaikan sarana dan prasarana yang dilaporkan. Berikut gambar sistem yang menampilkan pesan berhasil mengirim laporan dapat dilihat pada gambar 7 .

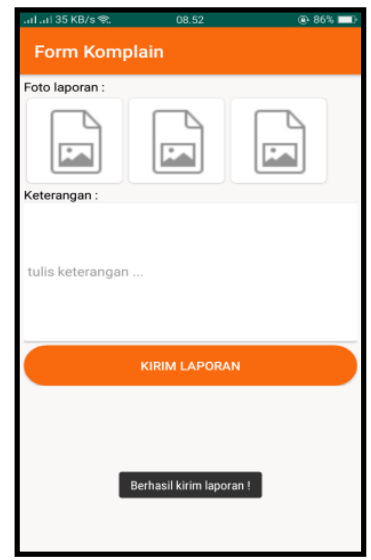

Gambar 7. Pesan Berhasil Mengirim Laporan

Sistem akan mengirim notifikasi laporan masuk kepada kepala unit untuk meminta persetujuan pengiriman laporan komplain kepada unit perlengkapan.

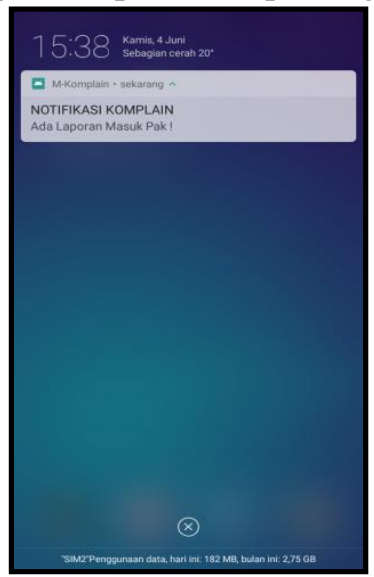

Gambar 8. Notifikasi Laporan Pada Kepala Unit

Setelah kepala unit memberi persetujuan pengiriman maka sistem mengirim notifikasi laporan masuk kepada kepala bagian unit perlengkapan untuk meminta konfirmasi. 


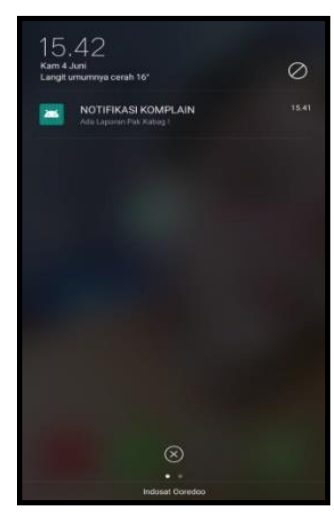

\section{Gambar 9. Notifikasi Laporan Pada Kepala Bagian Perlengkapan}

Sistem akan mengirim notifikasi laporan masuk dan tugas untuk menangani laporan komplain kepada teknisi yang dipilih oleh kepala bagian perlengkapan pada saat melakukan konfirmasi laporan komplain.

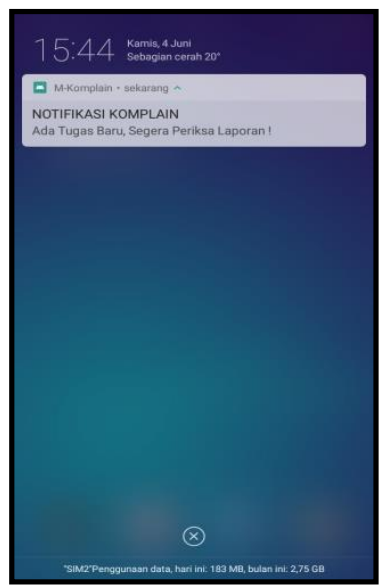

\section{Gambar 10. Notifikasi Laporan Pada Teknisi Perlengkapan}

Setelah sistem mampu berjalan dengan baik dan tidak ada kesalahan maka selanjutnya dilakukan pengujian User Acceptance Test (UAT) yang melibatkan 11 responden. Pengujian dilakukan dengan menggunakan angket yang memiliki 3 aspek penilaian yaitu aspek sistem, aspek pengguna, dan aspek interaksi. Hasil pengujian User Acceptance Test (UAT) yang didapatkan pada aspek sistem memperoleh nilai $83 \%$, pada aspek pengguna memperoleh nilai $88 \%$ dan pada aspek interaksi memperoleh nilai $87 \%$. Sedangkan untuk rata-rata keseluruhan diperoleh nilai $86 \%$.

\section{Kesimpulan}

Berdasarkan hasil penelitian yang telah dilakukan oleh peneliti menyimpulkan bahwa telah berhasil membangun sistem informasi pelaporan komplain dan monitoring perbaikan sarana prasarana pada Universitas Kanjuruhan Malang menggunakan model pengembangan waterfall berbasis android yang mampu mengirimkan laporan komplain, menampilkan keterangan penanganan, dan mengirim notifikasi laporan komplain. Berdasarkan hasil perhitungan User Acceptance Test (UAT) untuk pengujian kelayakan aplikasi, diperoleh $86 \%$ yang menyatakan setuju jika sistem pelaporan komplain dan monitoring perbaikan sarana prasarana digunakan pada Universitas Kanjuruhan Malang.

\section{Saran} berikut :

Adapun saran yang ditujukan untuk memberikan masukan yang lebih baik adalah sebagai 
1. Bagi unit perlengkapan dan unit yang lain agar memahami informasi yang diberikan sistem dengan baik dan disarankan untuk melakukan perawatan sistem secara berkala.

2. Pada penelitian lebih lanjut disarankan untuk menggunakan bahasa pemrograman lain seperti javascript dengan framework react native untuk mempercepat proses pembangunan sistem dan dapat berjalan di sistem operasi ios maupun android.

\section{DAFTAR PUSTAKA}

Ade Hendini. 2016. "Pemodelan UML Sistem Informasi Monitoring Penjualan Dan Stok Barang (Studi Kasus : Distro Zhezha Pontianak)". Jurnal Khatulistiwa Informatika. 4. 107-116.

Dwanoko, Y. S. 2016. Implementasi Software Development Life Cycle ( Sdlc ) Dalam Penerapan Pembangunan Aplikasi Perangkat. Jurnal Teknologi Informasi, 7(2), 83-94.

Pressman, R.S. 2015. Rekayasa Perangkat Lunak: Pendekatan Praktisi Buku I. Yogyakarta: Andi

Tabrani, M., \& Aghniya, I. R. 2019. Implementasi Metode Waterfall Pada Program Simpan Pinjam KOPERASI SUBUR JAYA MANDIRI SUBANG. Jurnal Interkom, 14(1), 44-53.

Wahyuningsih, Y. 2017. Pengembangan Aplikasi Test Online dengan Menggunakan Framework CodeIgniter di SMK Darul Ma'wa Plumpang pada Mata Pelajaran Jaringan Dasar Kelas X. It-Edu, 2(02), 36-46. 